\title{
Application of Real-Time and Multiplex Polymerase Chain Reaction Assays to Study Leaf Blotch Epidemics in Barley
}

\author{
J. M. Fountaine, M. W. Shaw, B. Napier, E. Ward, and B. A. Fraaije
}

First author: Plant-Pathogen Interactions Division, Rothamsted Research, Harpenden, Hertfordshire, AL5 2JQ, U.K. and School of Plant Sciences, The University of Reading, Reading, Berkshire, RG6 6AS, U.K.; second author: School of Plant Sciences, The University of Reading, U.K.; third author: National Institute of Agricultural Botany, Cambridge, Cambridgeshire, CB3 0LE, U.K.; and fourth and fifth authors: Plant-Pathogen Interactions Division, Rothamsted Research.

Accepted for publication 20 September 2006.

\begin{abstract}
Fountaine, J. M., Shaw, M. W., Napier, B., Ward, E., and Fraaije, B. A. 2007. Application of real-time and multiplex polymerase chain reaction assays to study leaf blotch epidemics in barley. Phytopathology 97:297303.

Leaf blotch, caused by Rhynchosporium secalis, was studied in a range of winter barley cultivars using a combination of traditional plant pathological techniques and newly developed multiplex and real-time polymerase chain reaction (PCR) assays. Using PCR, symptomless leaf blotch colonization was shown to occur throughout the growing season in the resistant winter barley cv. Leonie. The dynamics of colonization through-

10-fold higher in the susceptible cultivar, which expressed symptoms throughout the growing season. Visual assessments and PCR also were used to determine levels of $R$. secalis colonization and infection in samples from a field experiment used to test a range of winter barley cultivars with different levels of leaf blotch resistance. The correlation between the PCR and visual assessment data was better at higher infection levels $\left(R^{2}=0.81\right.$ for leaf samples with $>0.3 \%$ disease $)$. Although resistance ratings did not correlate well with levels of disease for all cultivars tested, low levels of infection were observed in the cultivar with the highest resistance rating and high levels of infection in the cultivar with the lowest resistance rating.
\end{abstract} out the growing season were similar in both Leonie and Vertige, a susceptible cultivar. However, pathogen DNA levels were approximately

Leaf blotch is the most economically important disease of barley (Hordeum vulgare L.) in the United Kingdom. The losses from disease in winter barley are approximately $£ 5$ million (\$US 9 million) per annum, and $£ 2.57$ million (\$US 4.6 million) of this is estimated to be due to Rhynchosporium secalis infection (8). The main control measure to limit yield loss is the combined use of fungicides and resistant cultivars. However, this is constantly under review because the pathogen is able to adapt to host plant resistance and develop fungicide resistance.

Guides are available for advisors and growers to select more resistant cultivars in areas with high disease pressure (e.g., HomeGrown Cereals Authority [HGCA], London, Recommended Lists; provided online by HGCA). These guides are produced following a series of experimental trials where winter and spring cereals are assessed for their susceptibility to common diseases affecting crop yield and quality.

At least 14 alleles involved in resistance to $R$. secalis in barley have been described and mapped (17). The U.K. Pathogen Virulence Survey tests different $R$. secalis isolates for their virulence to a range of cultivars carrying different resistance genes. In these tests, visual symptoms of $R$. secalis colonization are assessed following inoculation with spore suspensions.

Individual cultivars tend to react differently to $R$. secalis infection at different plant growth stages (16). However, visual disease assessments for the Recommended List field trials usually are carried out at only three different growth stages during the late season. Determination of $R$. secalis levels by scoring visual symptoms only does not allow detection of early-season or

Corresponding author: B. A. Fraaije; E-mail address: bart.fraaije@bbsrc.ac.uk

DOI: 10.1094/PHYTO-97-3-0297

(C) 2007 The American Phytopathological Society
Additional keywords: epidemic development.

symptomless infection and, therefore, may not reflect yield losses accurately.

Molecular diagnostic methodologies have been developed to enable detection of small amounts of pathogen. Foroughi-Wehr et al. (5) produced an enzyme-linked immunosorbent (ELISA) assay that was able to detect $R$. secalis in symptomless leaves. However, immunological assays can lack specificity and generally are $\approx 100$-fold less sensitive than DNA detection methods based on the polymerase chain reaction (PCR) (9). R. secalis has been detected in symptomless seed using conventional PCR (11) and infection levels in seed were quantified using competitive PCR (12). However, these methods are time consuming and laborious.

Real-time PCR has several advantages over conventional PCR for the detection and quantification of pathogens; it is faster, it allows for high throughput testing, and post-reaction processing steps are not needed, thereby limiting the risk of contamination $(15,20)$.

The objective of this research was to develop and apply multiplex and real-time PCR assays to detect and quantify foliar colonization and infection levels of $R$. secalis in winter barley. The sensitivity and specificity of PCR assays using different target genes were compared with visual assessment scores. Epidemics of $R$. secalis in a resistant and a susceptible cultivar were followed throughout the season using quantitative real-time PCR measurements. The potential of PCR testing to assess varietal resistance to barley leaf blotch also was investigated by assessing infection levels of 10 different cultivars grown in a Recommended List field trial.

\section{MATERIALS AND METHODS}

Field trial at Rothamsted. Two plots of 12 by $12 \mathrm{~m}$ containing resistant cv. Leonie (rating $=9$ ) and susceptible cultivar Vertige 
(rating $=5$ ) were drilled in Great Knott Field, Rothamsted on 4 October 2001 at a rate of $350 \mathrm{seed} / \mathrm{m}^{2}$. The two plots were separated on all sides by a guard of at least $3 \mathrm{~m}$ and drilled with wheat to limit the spread of inoculum from plot to plot by rain splash. These plots received no fungicide application throughout the growing season, but all other inputs were made in line with standard farm practice. The trial plots were harvested on 29 July 2002.

Plants from both cultivars were sampled twice monthly during the growing season from crop emergence until senescence. Ten plants were taken from a W-shaped transect across each plot. Plant growth stages at sampling were recorded using the Tottman (19) cereal growth keys. Plants were rinsed in running tap water to remove soil from the leaf surfaces and separated into leaf layers (flag, leaf 2, leaf 3, and so on). Individual leaf layers from each set of 10 plants were bulked together prior to DNA extraction.

Recommended List field trial at Cambridge. The field experiment was set up according to the HGCA Recommended List cereal trials protocol 2001/2002 (1). Leaf samples were taken from one of these trials in field 53 at the National Institute of Agricultural Botany in Cambridge. This trial was drilled on 28 September 2001 at $350 \mathrm{seed} / \mathrm{m}^{2}$ into plots of 1.5 by $9 \mathrm{~m}$ divided by an interplot gap of $0.5 \mathrm{~m}$, with two replicates per cultivar using a randomized plot design. The trial plots did not receive any fungicide application, but all other standard farm practices were performed. The crop was harvested on 30 July 2002. Plants were sampled from the plots on 12 May 2002 at growth stage 45 and leaves were visually assessed using the HGCA protocol and disease scale described by the HGCA (1).

DNA extraction and quantification. DNA was extracted from leaves (10 pooled leaves) and fungal material using the method of Fraaije et al. (7), except that the DNA extraction buffer was amended with $5 \mathrm{mM} \mathrm{1,10-phenanthroline} \mathrm{monohydrate}$ and $2 \%$ (wt/vol) polyvinylpyrrolidone K30 (Sigma-Aldrich Chemie $\mathrm{GmbH}$, Steinheim, Germany) to clean up DNA (22). The DNA was quantified using the fluorescent dye thiazole orange (SigmaAldrich) as described previously (6).

Amplification and cloning of PCR target sequences. Standard PCR was carried out in a Biometra T3 thermocycler (Biotron $\mathrm{GmbH}$, Goettingen, Germany) with 1.25 units of Red Hot DNA polymerase (ABgene, Epsom, UK), $20 \mathrm{mM}\left(\mathrm{NH}_{4}\right)_{2} \mathrm{SO}_{4}$, $75 \mathrm{mM}$ Tris-HCl (pH 9.0), 0.01\% Tween 20, $1.5 \mathrm{mM} \mathrm{MgCl}_{2}$, $125 \mu \mathrm{M}$ each dNTP, $0.5 \mu \mathrm{M}$ primers, and $1 \mathrm{ng}$ of template DNA in a final volume of $100 \mu$ l. For amplification of the cytochrome $b$ gene fragment using primer set Rscbf3/r3 (Table 1), conditions were $94^{\circ} \mathrm{C}$ for $2 \mathrm{~min} 30 \mathrm{~s}$; followed by 40 cycles of $94^{\circ} \mathrm{C}$ for $30 \mathrm{~s}$, $55^{\circ} \mathrm{C}$ for $1 \mathrm{~min}$, and $72^{\circ} \mathrm{C}$ for $1 \mathrm{~min} 30 \mathrm{~s}$; and a final extension at $72^{\circ} \mathrm{C}$ for $8 \mathrm{~min} 30 \mathrm{~s}$. For amplification of the $R$. secalis $\beta$-tubulin gene fragments using primer sets Rsf1/r1 and Rsf2/r2 (Table 1), the conditions were $94^{\circ} \mathrm{C}$ for $2 \mathrm{~min} 30 \mathrm{~s}$; followed by 35 cycles of $94^{\circ} \mathrm{C}$ for $30 \mathrm{~s}, 65^{\circ} \mathrm{C}$ for $1 \mathrm{~min}$, and $72^{\circ} \mathrm{C}$ for $1 \mathrm{~min} 30 \mathrm{~s}$; and a final extension at $72^{\circ} \mathrm{C}$ for $8 \mathrm{~min} 30 \mathrm{~s}$. PCR products were separated on ethidium bromide-stained $1.3 \%$ (wt/vol) agarose gels run in Tris-borate-EDTA (TBE) buffer ( $89 \mathrm{mM}$ Tris base, $89 \mathrm{mM}$ boric acid, $2 \mathrm{mM}$ EDTA, $\mathrm{pH}$ 8.0) and exposed to UV light to visualize DNA fragments.

PCR products were purified with the High Pure PCR Product Purification Kit (Boehringer, Mannheim, Germany) and ligated into pGEM-T easy (Promega Corp., Madison, WI). Plasmids were transformed into Escherichia coli JM109 cells (Promega Corp.) as described by Sambrook et al. (18). Plasmid DNA was extracted using the RPM Kit (Bio101 Inc, Carlsbad, CA). Nucleotide sequences were determined by the dideoxy chain termination method, at Durham University Sequence Centre (Durham, UK).

Primer and probe design. For detection of $R$. secalis using the $\beta$-tubulin gene (GenBank accession no. X81046) as the target, primer set Btrsf1/Btrsr1 and probe Btrsp1 (Table 1) were designed from conserved species-specific intron sequences using the primer design software Primer Express 1.5 (PE, Applied Biosystems). Forward and reverse primers targeting the cytochrome $b$ gene (DQ463419) were designed to have high GC content and, if possible, mismatches in the last four bases at the $3^{\prime}$ ends. This was done by aligning conserved $R$. secalis cytochrome $b$ sequences with those from other fungi, including Blumeria graminis f. sp tritici (AF343441), Aspergillus niger (AB000577), Fusarium oxysporum (AY874423.1), Mycosphaerella graminicola (AY247413), and Venturia inaequalis (AF004559) (data not shown). Due to the conserved nature and high AT content of the cytochrome $b$ gene at the desired target region of the gene, it was not possible to design a standard TaqMan probe for $R$. secalis. However, it was possible to design a locked nucleic acid (LNA) probe for $R$. secalis (Table 1). LNA probes are shorter than conventional TaqMan probes but have increased thermodynamic stability and enhanced nucleic acid recognition (13). For detection of the host, a region of the chloroplast subunit B of the ATPase gene (23) was targeted, and primers and probe were designed using Primer Express 1.5 software.

The specificity of all primers and probes used was checked using the National Center for Biotechnology Information BLAST server and confirmed by testing a panel of fungi, including Rhizoctonia cerealis, Oculimacula yallundae, Pyrenopeziza bras-

TABLE 1. Oligonucleotides used for cloning, multiplex polymerase chain reaction (PCR), and real-time PCR measurements

\begin{tabular}{|c|c|c|c|}
\hline Oligonucleotide name & Oligonucleotide type & Sequences $\left(5^{\prime}-3^{\prime}\right)$ and labeling & Target gene \\
\hline Rscbf3 & Forward primer & TTTARKTATACAAATWRTAACAGG ${ }^{\mathrm{a}}$ & Cytochrome $b$ \\
\hline Rscbr3 & Reverse primer & ССTAATAATTTATTAGGTATAGATCTTA & Cytochrome $b$ \\
\hline Rsbf2 & Forward primer & ATAGGTCAAGACATTGTTGAGTTTATC & Cytochrome $b$ \\
\hline Rsbr2 & Reverse primer & TGGAGTTTGCATAGGGTTAGCTAC & Cytochrome $b$ \\
\hline Rsf1 & Forward primer & ATGCGTGAAATCGTACGT & $\beta$-Tubulin \\
\hline Rsr1 & Reverse primer & GCGTTGTAAGGCTCTACC & $\beta$-Tubulin \\
\hline Rsf2 & Forward primer & CTCCCAAGGTCTCCGACA & $\beta$-Tubulin \\
\hline Rsr2 & Reverse primer & TTACTCCTCTGGCTCATA & $\beta$-Tubulin \\
\hline Barleyf2 & Forward primer & GCTACTCTCGGACGAATTTTC & ATPase subunit B \\
\hline Barleyr2 & Reverse primer & AGTTTCCATCGAGATCAGATACCG & ATPase subunit B \\
\hline Btrsf1 & Forward primer & TCTCCTACGCGTCTGCTCAA & $\beta$-Tubulin \\
\hline Btrsr1 & Reverse primer & TTAGTTGCGTGGTCT & $\beta$-Tubulin \\
\hline Btrsp1 & TaqMan probe & FAM-AGCTGCTACCCCACCACCCCCTT-TAMRA ${ }^{\mathrm{b}}$ & $\beta$-Tubulin \\
\hline Rsrtpcr1f & Forward primer & ATGTGCTTCCTTATGGACAGATGT & Cytochrome $b$ \\
\hline Rsrtpcr1r & Reverse primer & ATTATTAACAGAAAAACCCCCTCAGAT & Cytochrome $b$ \\
\hline Rsrtpcr1p & LNA probe & FAM-TATG*AG*GTGCC*AC*AGT-BHQ-1 ${ }^{\text {c }}$ & Cytochrome $b$ \\
\hline
\end{tabular}

a Primer with degenerate bases $\mathrm{R}=\mathrm{A}$ or $\mathrm{G}, \mathrm{K}=\mathrm{G}$ or $\mathrm{T}$, and $\mathrm{W}=\mathrm{A}$ or $\mathrm{T}$.

${ }^{b}$ Probe labeled with 6-carboxy fluorescein (FAM) and 6-tetra methyl-rhodamine (TAMRA).

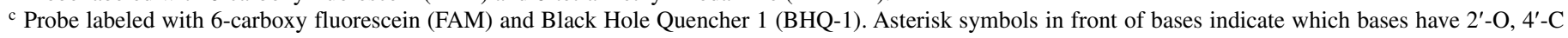
methylene linkages. 
sicae, M. graminicola, Stagonospora nodorum, F. graminearum, B. graminis, Pyrenophora teres, Puccinia striiformis, P. recondita, and Gaeumannomyces graminis. The absence of signals and PCR products in real-time PCR or gel electrophoresis, respectively, confirmed the specificity of the assays.

Multiplex PCR. Multiplex PCR was carried out in a Biometra T3 thermocycler with 0.5 unit of Red Hot DNA polymerase (ABgene), $20 \mathrm{mM}\left(\mathrm{NH}_{4}\right)_{2} \mathrm{SO}_{4}, 75 \mathrm{mM}$ Tris- $\mathrm{HCl}$ (pH 9.0), $0.001 \%$ (wt/vol) Tween $20,1.5 \mathrm{mM} \mathrm{MgCl} 2,125 \mu \mathrm{M}$ each dNTP, $0.5 \mu \mathrm{M}$ primers (Table 1 , sets Barleyf $2 / \mathrm{r} 2$ and Rsbf2/r2), and $50 \mathrm{ng}$ of template DNA in a final volume of $25 \mu \mathrm{l}$. The PCR conditions were $94^{\circ} \mathrm{C}$ for $2 \mathrm{~min} 30 \mathrm{~s}$; followed by 40 cycles of $94^{\circ} \mathrm{C}$ for $30 \mathrm{~s}$, $55^{\circ} \mathrm{C}$ for $1 \mathrm{~min}$, and $72^{\circ} \mathrm{C}$ for $1 \mathrm{~min} 30 \mathrm{~s}$; with a final extension at $72^{\circ} \mathrm{C}$ for $8 \mathrm{~min} 30 \mathrm{~s}$. PCR products were separated on ethidium bromide-stained $1.3 \%$ (wt/vol) agarose gels run in TBE buffer and exposed to UV light to visualize DNA fragments of 333 and 399 bp (R. secalis and barley, respectively).

Real-time PCR assays. For the $\beta$-tubulin TaqMan assay, each reaction contained $12.5 \mu \mathrm{l}$ of PCR master-mix $(60 \mathrm{U} / \mathrm{ml}$ Platinum Taq DNA polymerase, $40 \mathrm{mM}$ Tris- $\mathrm{HCl}, 100 \mathrm{mM} \mathrm{KCl}, 6 \mathrm{mM}$ $\mathrm{MgCl}_{2}, 400 \mu \mathrm{M}$ dGTP, $400 \mu \mathrm{M}$ dATP, $400 \mu \mathrm{M}$ dCTP, $800 \mu \mathrm{M}$ dUTP, UDG at $40 \mathrm{U} / \mathrm{ml}$, and stabilizers (Invitrogen Ltd., Paisley, $\mathrm{UK}$ ), $0.6 \mu \mathrm{M} \beta$-tubulin forward primer (Btrsf1), $0.2 \mu \mathrm{M} \beta$-tubulin reverse primer (Btrsr1), $0.2 \mu \mathrm{M}$ labeled probe (Btrsp1) (Table 1), $0.375 \mu \mathrm{l}$ of $50 \times$ ROX reference dye (Invitrogen Ltd.), and autoclaved distilled water to a final volume of $25 \mu \mathrm{l}$ in capped ThermoFast 96 PCR Plates (ABgene). Amplification of the 77-bp PCR product was performed in a PRISM 7700 Sequence Detection System under the following conditions: $50^{\circ} \mathrm{C}$ for $5 \mathrm{~s}$, 1 cycle at $94^{\circ} \mathrm{C}$ for $2 \mathrm{~min}$, followed by 50 cycles at $95^{\circ} \mathrm{C}$ for $15 \mathrm{~s}$ and at $60^{\circ} \mathrm{C}$ for $1 \mathrm{~min}$. The increase in fluorescent emission from cleaved probes was registered at $60^{\circ} \mathrm{C}$ and data analyzed with Sequence Detector Software version 1.9.

For the cytochrome $b$ SYBR-Green I assay, each reaction $(25 \mu \mathrm{l}$ per well) contained $50 \mathrm{ng}$ of template DNA, $150 \mu \mathrm{M}$ each dNTP, $0.3 \mu \mathrm{M}$ each primer (Table 1, set Rsbf2/r2), 0.35 units of Red Hot DNA polymerase (ABgene), and $1 \times$ SYBR Green I (Molecular Probes, Leiden, the Netherlands). Amplification of the 333-bp PCR product was performed in a PRISM 7700 Sequence Detection System (PE, Applied Biosystems) under the following conditions: $50^{\circ} \mathrm{C}$ for $5 \mathrm{~s}, 1$ cycle at $94^{\circ} \mathrm{C}$ for $2 \mathrm{~min} 30 \mathrm{~s}$, followed by 45 cycles at $94^{\circ} \mathrm{C}$ for $30 \mathrm{~s}, 56^{\circ} \mathrm{C}$ for $45 \mathrm{~s}$, and $72^{\circ} \mathrm{C}$ for $1 \mathrm{~min}$. The increase of SYBR Green I fluorescence, measured upon binding with double-stranded DNA at $72^{\circ} \mathrm{C}$, was analyzed with the Sequence Detector Software version 1.9 (PE, Applied Biosystems).

For the cytochrome $b$ LNA probe assay, each well contained $5 \mu$ of template DNA and $15 \mu$ of reaction mix. Reaction mix consisted of $10 \mu \mathrm{l}$ of PCR master mix (JumpStart Taq ReadyMix, $20 \mathrm{mM}$ Tris $\mathrm{HCl}$ [pH 8.3], $100 \mathrm{mM} \mathrm{KCl}, 3 \mathrm{mM} \mathrm{MgCl}, 0.002 \%$ gelatine, $0.4 \mathrm{mM}$ each dNTP, stabilizers, 0.06 unit $\mu \mathrm{l}^{-1}$ Taq DNA polymerase, JumpStart Taq antibody) (Sigma-Aldrich, St. Louis, USA), $0.4 \mu \mathrm{M}$ forward primer Rsrtpcr1f, $0.4 \mu \mathrm{M}$ reverse primer Rsrtpcr1r, $0.1 \mu \mathrm{M}$ LNA fluorogenic probe Rstpcr1p (Table 1), $0.1 \mu \mathrm{l}$ of $50 \times$ ROX reference dye (Sigma-Aldrich), and sterile distilled water. Amplification of the 125-bp PCR product was carried out in a Stratagene Mx3000P real-time PCR machine
(Stratagene, La Jolla, CA) under the following conditions: 1 cycle at $94^{\circ} \mathrm{C}$ for $10 \mathrm{~min}$, followed by 50 cycles at $95^{\circ} \mathrm{C}$ for $15 \mathrm{~s}$ and $60^{\circ} \mathrm{C}$ for $1 \mathrm{~min}$. The increase of fluorescence from the probe was recorded at $60^{\circ} \mathrm{C}$.

For all real-time PCR assays, samples were run in duplicate. For each sample, the threshold cycle $(\mathrm{Ct}$; cycle at which increase of fluorescence exceeded the background) was determined. Samples detected earlier than control samples (50 ng of DNA extracted from "clean" barley leaves sampled from plants grown in a glasshouse) were regarded as positive. Plotting known amounts of target DNA against $\mathrm{Ct}$ values generated standard curves. Calibration curves were generated by spiking barley leaf DNA samples (50 ng of DNA) with eight different amounts of genomic Rhynchosporium secalis DNA (fivefold dilution series from $50 \mathrm{ng}$ to $0.0256 \mathrm{pg}$ ). Two negative controls, barley DNA and sterile distilled water, and all standard curve samples were run simultaneously with test samples in each real-time PCR experiment. For all experiments conducted in this study, standard curves with $R^{2}$ values $>0.95$ were obtained.

Data analysis. In order to compare $R$. secalis epidemic development in the top four leaf layers of two different cultivars over time in the field trial at Rothamsted, pathogen DNA levels were plotted against thermal time according to Lovell et al. (14). For the Recommended List field trial at Cambridge, the visual assessment and quantitative real-time PCR data sets were transformed using natural logarithms $(\ln )$ to normalize the data. Results and correlations between visual assessment and fungal biomass (DNA) were examined with an analysis of variance (ANOVA) using Genstat (8th edition; VSN International, Ltd., Hemel Hempstead, UK). The weather data for the 2001-02 growing season were obtained from the Electronic Rothamsted Archive Meteorological Database.

\section{RESULTS}

Cloning and sequencing of cytochrome $\boldsymbol{b}$ and $\beta$-tubulin gene fragments. PCR assays for $R$. secalis detection were designed using DNA sequences of cytochrome $b$ (DQ463419) and $\beta$ tubulin (X81046) as targets. In order to check for sequence variation, additional homologous sequences were obtained from $R$. secalis isolates K1124, 5.2 5/7, and LARS 7 (Table 2). For the cytochrome $b$ gene, a DNA fragment of 759 bp was amplified using the primer set Rscbf3/r3 (Table 1). For the $\beta$-tubulin gene, two primer sets Rsf1/Rsr1 and Rsf2/r2 (Table 1) were used, resulting in a 1,780-bp full-length amplification of the gene (21).

Evaluation of the sensitivity and specificity of the real-time PCR assays. The three different real-time PCR assays ( $\beta$-tubulin TaqMan probe, cytochrome $b$ SYBR-Green I, and cytochrome $b$ LNA probe assay) were optimized with regard to primer and probe concentrations. Specificity was checked by testing DNA of nine $R$. secalis isolates obtained from different geographical areas (Table 2) and a panel of fungal species (described previously). All assays were highly specific for detection of $R$. secalis; no fluorescent signals were obtained for DNA of the other fungi tested. The cytochrome $b$ LNA probe assay was most sensitive; it

TABLE 2. Isolates of Rhynchosporium secalis used for primer and probe design

\begin{tabular}{lccl}
\hline Isolate designation & Barley type & Year & Origin \\
\hline K1124 & Winter barley & Unknown & Long Ashton Research Station, Bristol \\
SK7 & Winter barley & 1984 & Long Ashton Research Station, Bristol \\
LARS7 & Winter barley & 1985 & Long Ashton Research Station, Bristol \\
$2.15 / 7$ & Winter barley & 2001 & Rothamsted Research, Hertfordshire \\
$3.25 / 7$ & Winter barley & 2001 & Rothamsted Research, Hertfordshire \\
$5.25 / 7$ & Winter barley & 2001 & Rothamsted Research, Hertfordshire \\
$6.25 / 7$ & Winter barley & 2001 & Rothamsted Research, Hertfordshire \\
M.S 5.11 3/7 & Spring barley & 2001 & Trenthome Farm, Nottingham \\
SAC 1.15 & Winter barley & 2000 & Scottish Agricultural College, Edinburgh \\
\hline
\end{tabular}


could detect as little as $0.1 \mathrm{pg}$ of $R$. secalis DNA in the presence of $50 \mathrm{ng}$ of barley leaf DNA. The detection thresholds for the cytochrome $b$ SYBR-Green I and $\beta$-tubulin TaqMan probe assay were 1.0 and $3.0 \mathrm{pg}$ of pathogen DNA, respectively, in the presence of $50 \mathrm{ng}$ of barley leaf DNA.

Leaf blotch epidemics in a resistant and a susceptible cultivar of winter barley measured by visual assessment and multiplex and quantitative PCR. For susceptible cv. Vertige, severe symptoms of leaf blotch were recorded from mid-February until the end of the growing season; whereas, for resistant cv. Leonie, only one lesion was observed at the end of the season (Table 3).

Using the multiplex PCR assay, $R$. secalis was shown to be present in both Vertige and Leonie at all stages of the growing season sampled (from April onward) (Fig. 1) even in the absence of symptoms. For some older leaf samples (lower, earlieremerged leaves), the target barley chloroplast DNA was not amplified, presumably due to degradation of DNA in dead leaf tissues or an excess of pathogen DNA in these samples.

Because the multiplex PCR assay is not quantitative, the $\beta$ tubulin TaqMan probe assay was used to quantify the $R$. secalis colonization levels in the leaf samples; the more sensitive cytochrome $b$ LNA real-time PCR assay had not been developed when this part of the study was undertaken. DNA of $R$. secalis

TABLE 3. Number of leaf blotch lesions found at different stages of the growing season during 2002 in plots of the winter barley cvs. Vertige and Leonie $^{\mathrm{a}}$

\begin{tabular}{lccccc}
\hline & \multicolumn{2}{c}{ Vertige } & & \multicolumn{2}{c}{ Leonie } \\
\cline { 2 - 3 } \cline { 5 - 6 } Sample date & Lesions & GS & & Lesions & GS \\
\hline 15 February & 12 & 25 & & 0 & 23 \\
25 February & 15 & 27 & & 0 & 24 \\
14 March & 23 & 29 & & 0 & 26 \\
27 March & 33 & 30 & & 0 & $27 / 28$ \\
18 April & 38 & 31 & & 0 & 28 \\
26 April & 42 & 33 & & 0 & 30 \\
08 May & 89 & 44 & & 0 & 39 \\
06 June & 127 & 56 & & 0 & 48 \\
19 June & 213 & 71 & & 1 & 65 \\
\hline
\end{tabular}

${ }^{\mathrm{a}}$ Lesions $=$ number of lesions on 10 plants and GS $=$ crop growth stage. was detected in both cultivars, but leaves of $\mathrm{cv}$. Vertige contained $\approx 10$-fold more pathogen DNA than Leonie (Fig. 2). Interestingly, although visual symptoms were mostly absent on leaves of the resistant cv. Leonie, an identical pattern of $R$. secalis colonization dynamics over time was observed for both cultivars when PCR pathogen DNA levels in leaf layer were plotted against accumulated thermal time (Fig. 2).
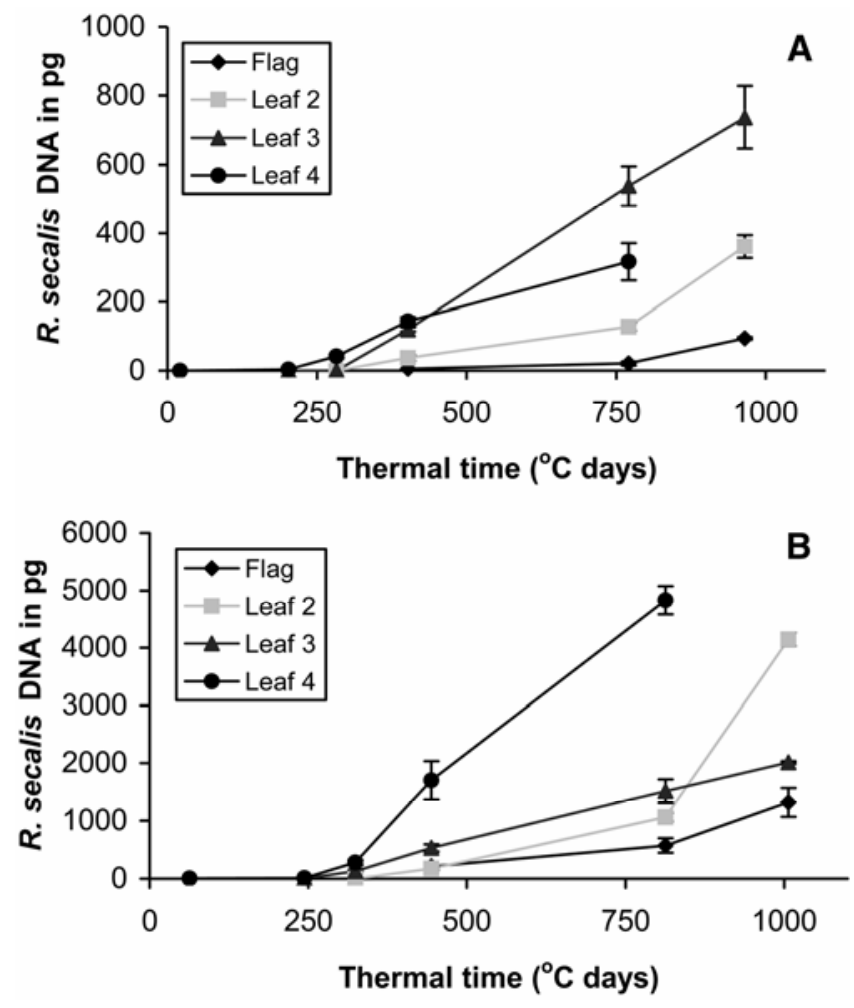

Fig. 2. Levels of Rhynchosporium secalis DNA measured by $\beta$-tubulin TaqMan real-time polymerase chain reaction in leaf layers of winter barley cvs. A, Leonie and B, Vertige. Pathogen DNA levels plotted against accumulated thermal time since sowing using $0^{\circ} \mathrm{C}$ as the base temperature (note different scaling for each cultivar). Error bars represent standard errors.

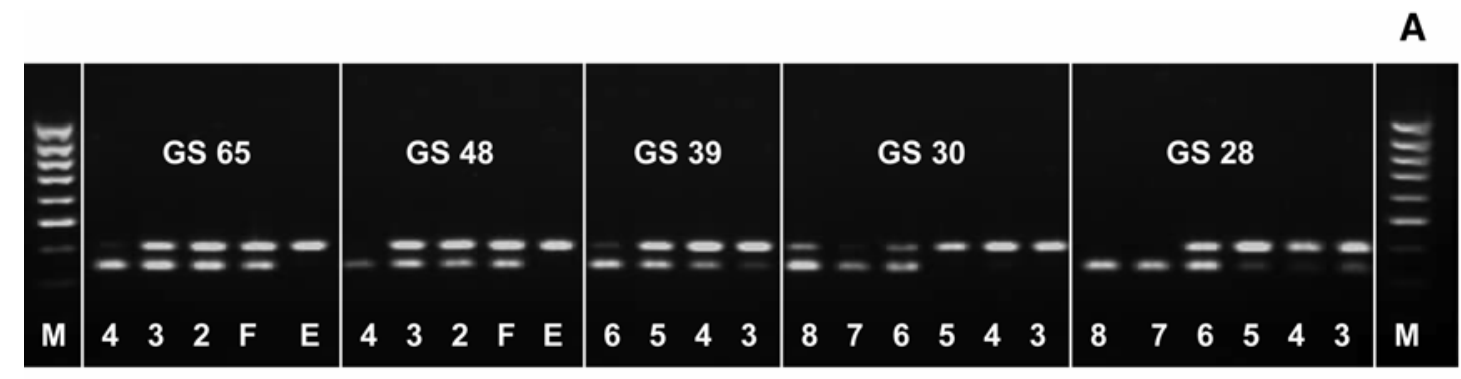

B

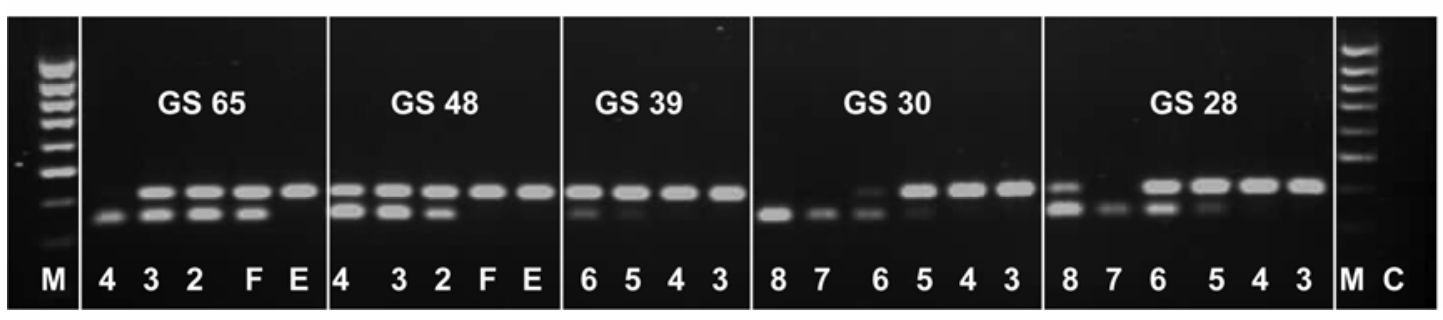

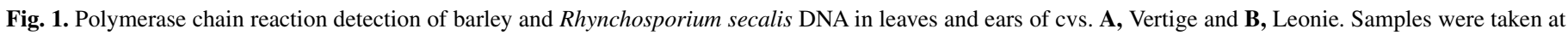

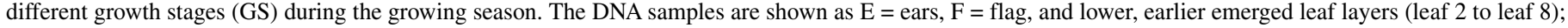

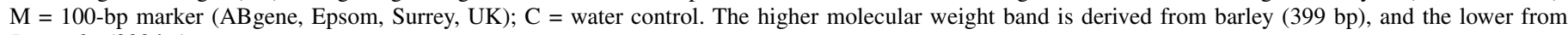
R. secalis (333 bp). 
Application of multiplex and real-time PCR assays to assess leaf blotch susceptibility in different barley cultivars. Both the multiplex PCR and the three different real-time PCR assays were used to screen 10 different barley cultivars grown at the Recommended List trial at Cambridge for presence of $R$. secalis. Levels of leaf blotch also were assessed visually for comparison.

The visual disease levels recorded, with values between 0 and $6.5 \%$ for individual leaf layers, were much lower than in other years for which data were available (unpublished data). DNA of $R$. secalis was detected in all cultivars using multiplex PCR (Fig. 3). In some leaf layers of some cultivars (e.g., Vanessa and Leonie), $R$. secalis was not detected, indicating colonization of leaves in the absence of symptoms.

The results obtained with the three different real-time PCR assays were not significantly different $(P>0.5)$ and agreed very well with each other $\left(R^{2}>0.95\right)$ for leaf samples in which $R$. secalis was detected by all three assays (Fig. 4). As expected, due to its higher sensitivity, the cytochrome $b$ LNA probe assay was most sensitive, with 57 of the 60 leaf samples testing positive for presence of $R$. secalis (data not shown). In all, 45 and 53 of the 60 samples tested were found positive in the SYBR-Green I cytochrome $b$ and the $\beta$-tubulin TaqMan probe assays, respectively, whereas disease levels were recorded for only 44 samples (data not shown).

The results of visual assessments and $R$. secalis levels determined by real-time PCR in different leaf layers of the 10 cultivars of barley are shown in Table 4. High levels of colonization and disease were measured for cv. Sumo, which had the lowest resistance rating of the cultivars tested (rating $=5$ ), and low levels of colonization were recorded for Leonie, the cultivar with the highest resistance rating (rating $=9$ ) (Table 4). However, overall, there was poor correspondence between published resistance rating (based on visual assessments over several years at multiple sites), and either visual or PCR assessments.

There were no significant average differences between replicates in either the visual assessment or the PCR data (Table 4). Visual assessments of the different cultivars differed $(\mathrm{P}<0.001)$, but neither differences between leaves nor the interaction between leaves and cultivar were significant $(P>0.3)$. Analysis of variance of the PCR data showed that the main effects of leaf, cultivar, and their interactions all were significant at $P<0.001$ on both natural and log-transformed scales. Interactions arose in some cultivars as PCR values increased up the plant (e.g., Jewel and Angela); in most others, they decreased, as expected from a mainly rain-splash-dispersed pathogen.

The relationship between PCR data obtained with the cytochrome $b$ LNA probe assay and visual assessments was further tested using regression analysis (Fig. 5). The linear relationship produced an $R^{2}$ value of $0.60(n=25)$ and is statistically significant $(P<0.001)$. However, some curvature is apparent in

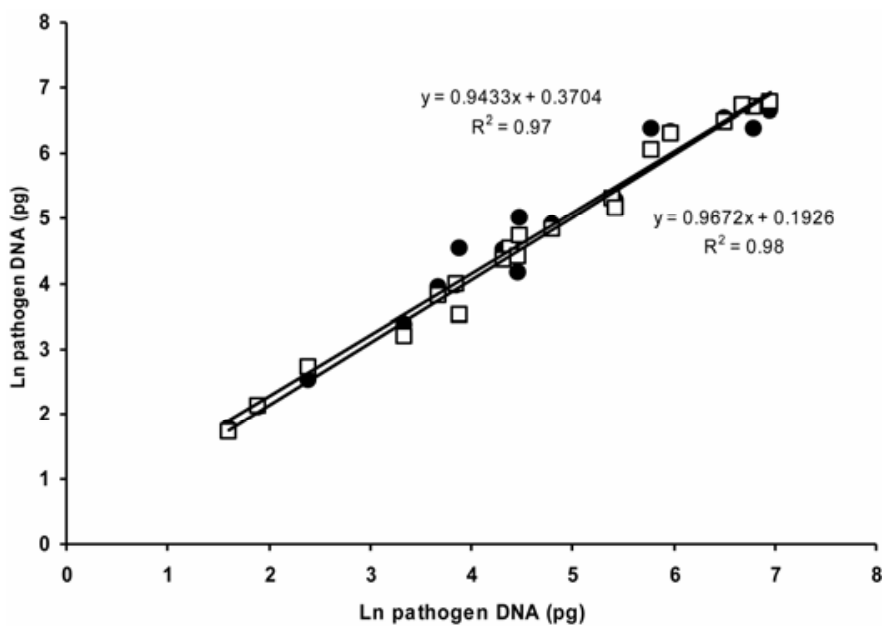

Fig. 4. Comparison between three quantitative real-time polymerase chain reactions for detection of Rhynchosporium secalis in leaves sampled from 10 different winter barley cultivars. Results using the $\beta$-tubulin TaqMan probe (solid circle, $R^{2}=0.97$ ) and SYBR Green I cytochrome $b$ (open square, $R^{2}=$ 0.98 ) assays ( $y$ axis) are plotted against the results of the cytochrome $b$ locked nucleic acid probe assay ( $x$ axis). Only data sets (mean values obtained for the two replicate plots) from samples detecting positive in all three assays were used in the analysis $(n=20)$.
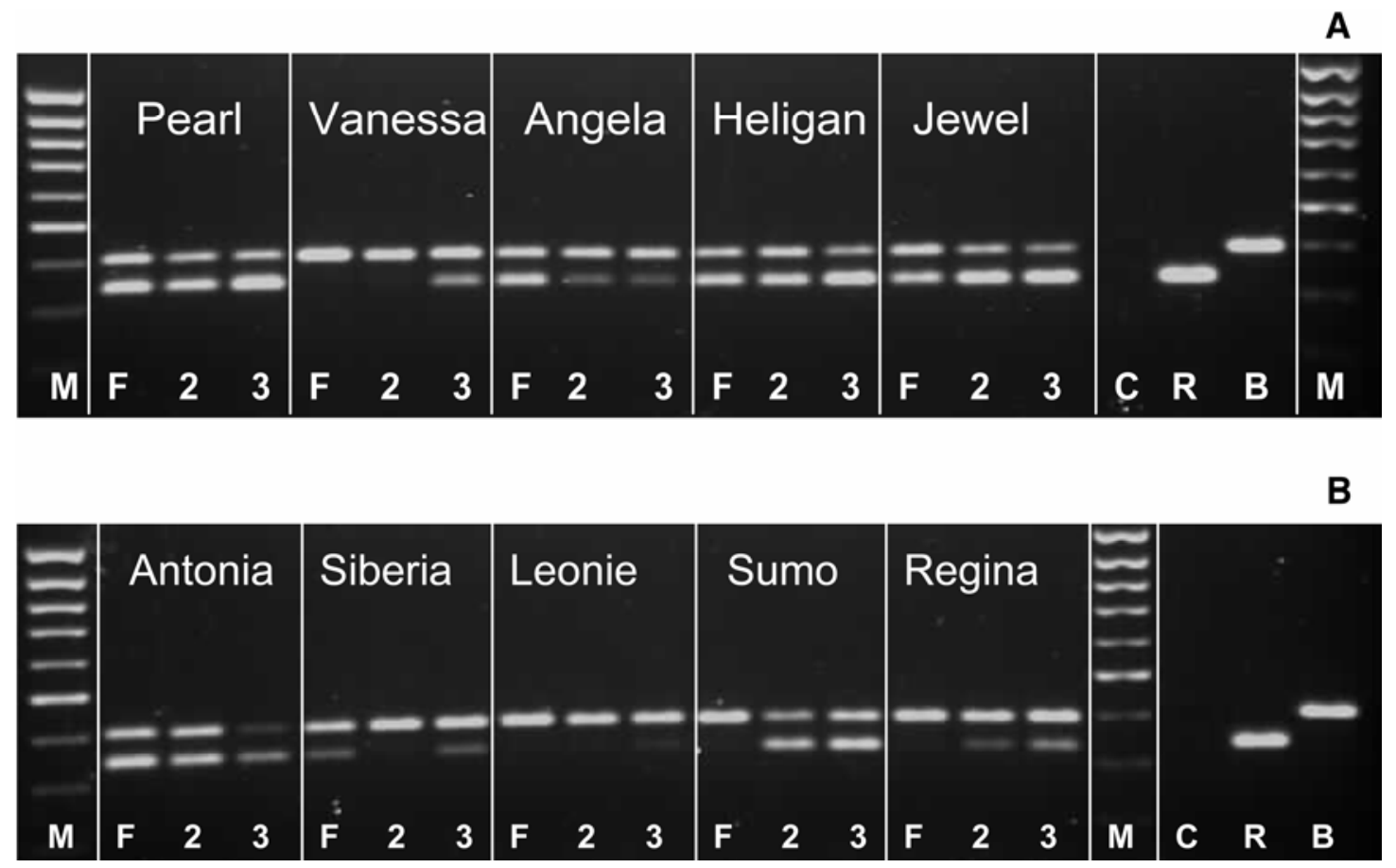

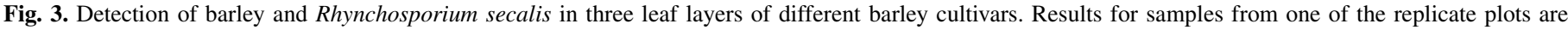

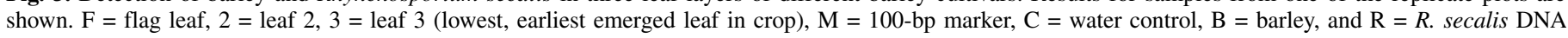
( $5 \mathrm{ng}$ ). The $R$. secalis amplicon is $333 \mathrm{bp}$ and the barley amplicon is $399 \mathrm{bp}$. 
Figure 5, mainly due to PCR detection of variable levels of $R$. secalis colonization in samples with low disease levels $(<0.3 \%)$ (e.g., leaf 3 of cv. Vanessa).

\section{DISCUSSION}

The multiplex PCR assay was a useful tool for determining the presence of $R$. secalis in the barley samples and simultaneously checking for the presence of PCR inhibitors. However, it is not a quantitative method and, therefore, real-time PCR assays were developed to determine the levels of $R$. secalis infection in various experimental samples.

The three real-time PCR assays developed in this study all were shown to be highly specific, with the LNA probe assay being most sensitive. In comparison with the TaqMan probe asay targeting the nuclear encoded $\beta$-tubulin gene, the LNA probe assay is more sensitive, probably due to the higher copy number of the mitochondrial-encoded cytochrome $b$ gene. Furthermore, the SYBR-Green I assay is less sensitive than the LNA probe assay, probably because there is higher background fluorescence due to the presence of nonspecific double-stranded DNA products (7).

Although symptomless infection by $R$. secalis previously had been shown to occur to a limited extent (4), this study revealed

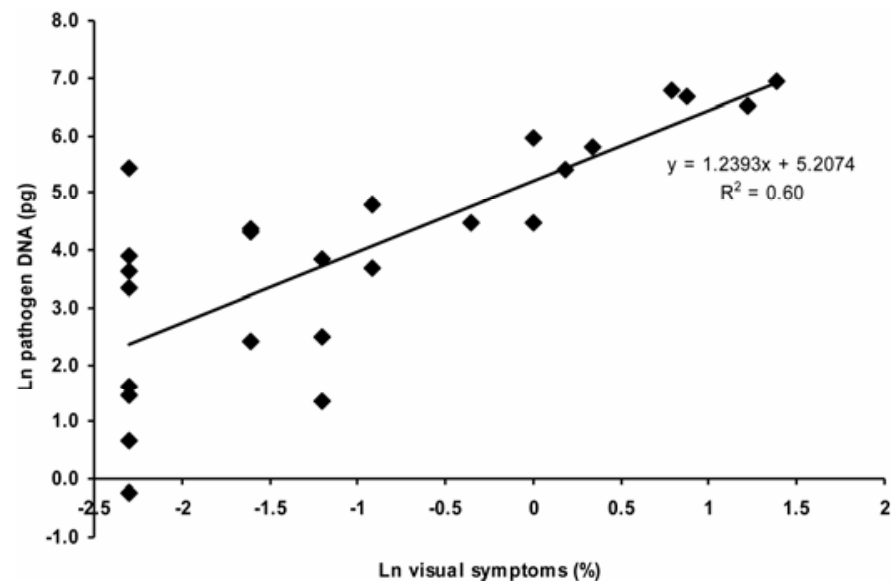

Fig. 5. Relationship between visual assessments (Ln percent leaf area infected) and quantitative real-time polymerase chain reaction (cytochrome $b$ LNA probe assay) for detection of Rhynchosporium secalis in leaf samples of 10 different winter barley cultivars. Mean values obtained for samples from the two replicate plots were used. that colonization can occur over most of the growing season in a resistant cultivar. The dynamics of colonization in the resistant $\mathrm{cv}$. Leonie followed a pattern similar to leaf blotch development in the susceptible cv. Vertige (Fig. 2). This study reinforces the work 130 carried out by Howlett and Cooke (10), who found that limited fungal growth could occur under the cuticle in resistant cultivars without causing symptoms of disease. It is not clear whether conidia are produced in symptomless leaves. The availability of inoculum throughout the season could be explained by growth within the plant after seed transmission or spore arrival. More testing is needed to assess whether symptomless infection also can affect yield and grain quality.

For samples taken from the Recommended List trial at Cambridge (Table 4), the correlation between the visual assessment data and pathogen infection levels detected by real-time PCR (Fig. 5) became more statistically significant as percentage of visual assessment scores increased $\left(R^{2}=0.81\right.$ for samples with disease levels $>0.3 \%, n=11$ ). However, for some cultivars, the colonization level measured using PCR was unexpectedly high in comparison with the visual assessment (e.g., leaf $3 \mathrm{of}$ cv. Vanessa) (Table 4). The formation of leaf blotch lesions in plants may occur only once the pathogen levels have reached a certain threshold. This may relate to the quantity of rhynchosporoside toxin produced (2), causing collapse of plant tissue and subsequent development of disease symptoms, or from activation of host resistance genes that suppress disease when small amounts of pathogen are present.

Overall, resistance ratings did not correlate well with the levels of disease detected by visual assessments or real-time PCR, and results of a few replicate plots showed variable results (data not shown). Three factors could be involved in this poor correlation. First, different $R$. secalis race structures may have been present in the locations and seasons on which the resistance ratings are based (3). Second, the disease in a particular small plot may have been influenced by initial inoculum because the replication was low. Third, the resistance reactions of cultivars may vary with environment, particularly disease pressure, due to induced resistance or other phenomena. The disease pressure affecting the trial reported here was relatively low.

This study shows clearly the benefit of using both real-time PCR and visual assessment in monitoring colonization and infection levels of $R$. secalis in leaf samples of different cultivars. More research will be needed to establish why some cultivars have a high colonization rate without showing symptoms. Future work also will involve the use of PCR diagnostics in determining the role of different inoculum sources in initiating leaf blotch

TABLE 4. Visual assessment scores and Rhynchosporium secalis infection levels determined by real-time polymerase chain reaction (PCR) (cytochrome $b$ locked nucleic acid probe assay) in 10 different cultivars of winter barley

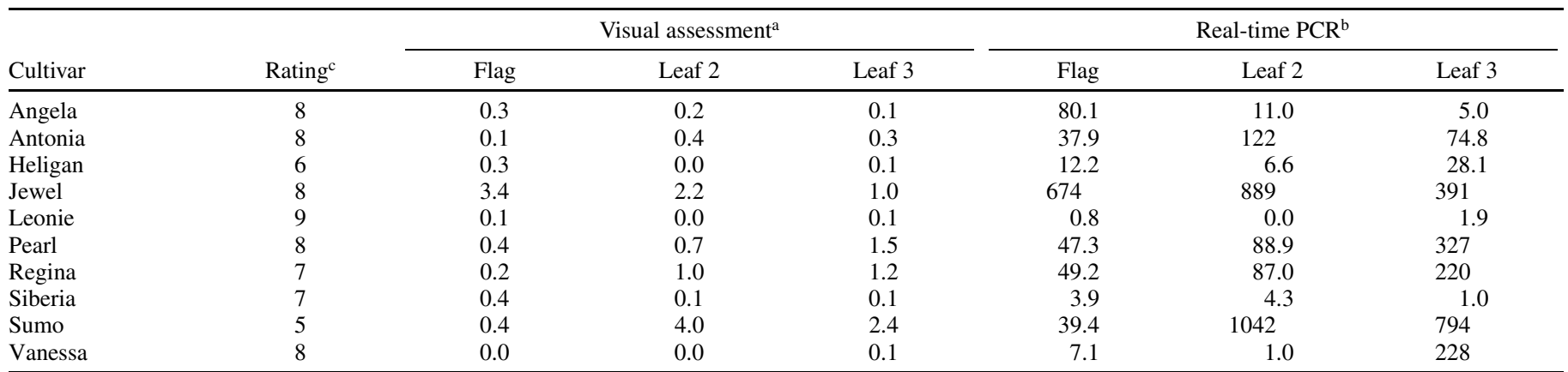

${ }^{a}$ Visual assessment scores are expressed as percentage of leaf area infected. Mean values over the two replicate plots are given. Least significant differences between values in table, 2.0. Analysis of variance (ANOVA): differences between cultivars, $P<0.001$; between leaves, $P=0.8$; leaf-cultivar interaction, $P<0.6$.

${ }^{\mathrm{b}}$ Real-time PCR results show amount of pathogen DNA (pg) per $50 \mathrm{ng}$ of sample tested. Mean values for the two replicate plots are given. The detection threshold of the assay is $0.1 \mathrm{pg}$. Samples below threshold were regarded as zero. Both main effects and interaction were significant $(P<0.001)$ in ANOVA after log transformation. Coefficient of variation in each measurement, 55\% of the mean value, based on standard error of the mean from ANOVA of log data.

${ }^{c}$ A resistance rating of 5 denotes a susceptible cultivar, likely to be severely affected under high disease pressure; 6 or 7 indicates a moderately resistant cultivar; and 8 or 9 denotes a resistant cultivar, disease unlikely. 
epidemics by studying seed transmission and dispersal of spores via rain-splash or air.

\section{ACKNOWLEDGMENTS}

This work was funded as part of a CASE Ph.D. studentship by the Biotechnology and Biological Sciences Research Council (BBSRC) and Syngenta crop protection. Rothamsted Research is grant-aided by BBSRC. We thank D. Yeoman and the farm staff for preparing the field experiment at Rothamsted; and H. Cools, J. Motteram, and S. Gilbert for their help and advice.

\section{LITERATURE CITED}

1. Anonymous, 2001. Home Grown Cereals Authority, Recommended list cereal protocol 2001/2002. Home-Grown Cereals Authority, London.

2. Auriol, P., Strobel, G., Piobeltran, J., and Gray, G. 1978. Rhynchosporoside, a host-selective toxin produced by Rhynchosporium secalis, causal agent of scald disease of barley. Proc. Natl. Acad. Sci. USA 75:4339-4343.

3. Beer, W. W. 1991. Leaf blotch of barley (Rhynchosporium secalis). Zentralbl. Mikrobiol. 146:339-358.

4. Davis, H., and Fitt, B. D. L. 1990. Symptomless infection of Rhynchosporium secalis on leaves of winter barley. Mycol. Res. 94:557-560.

5. Foroughi-Wehr, B., Zuchner, S., and Rabenstein, F. 1996. Enzyme-linked immunosorbent assay for detection of Rhynchosporium secalis (Oud) J. J. Davis in winter barley. Z. Pflanzenkrankh. Pflanzenschutz 103:267-271.

6. Fraaije, B. A., Cools, H. J., Fountaine. J. M., Lovell, D. J., Motteram, J., West, J. S., and Lucas, J. A. 2005. QoI resistant isolates of Mycosphaerella graminicola and the role of ascospores in further spread of resistant alleles in field populations. Phytopathology 95:933-941.

7. Fraaije, B. A., Lovell, D. J., Rohel, E. A., and Hollomon, D. W. 1999. Rapid detection and diagnosis of Septoria tritici epidemics in wheat using a polymerase chain reaction/PicoGreen assay. J. Appl. Microbiol. 86:701708.

8. Hardwick, N. V., Slough, J. E., and Gladders, P. 2002. Winter barley: A survey of disease 2002. Central Science Laboratory, York, UK.

9. Hollomon, D. W., Fraaije, B. A., Rohel, E., Butters, J. A., and Kendall, S. 1999. Detection and diagnosis of Septoria diseases: the problem in practice. Pages 273-285 in: Septoria on Cereals: A Study of Pathosystems. J. A. Lucas, P. Bowyer, and H. M. Anderson, eds. CABI publishing, Wallingford, Oxford, UK.
10. Howlett, S. G., and Cooke, B. M. 1992. More scanning electron micrographs of conidial production in Rhynchosporium secalis. Mycologist 6:16-17.

11. Lee, H. K., Tewari, J. P., and Turkington, T. K. 2001. Symptomless infection of barley seed by Rhynchosporium secalis. Can. J. Plant Pathol. 23:315-317.

12. Lee, H. K., Tewari, J. P., and Turkington, T. K. 2002. Quantification of seed-borne infection by Rhynchosporium secalis in barley using competitive PCR. Plant Pathol. 51:217-224.

13. Letertre, C., Perelle, S., Dilasser, F., Arar, K., and Fach, P. 2003. Evaluation of the performance of LNA and MGB probes in 5'-nuclease PCR assays. Mol. Cell. Probes 17:307-311.

14. Lovell. D. J., Powers, S. J., Welham, S. J., and Parker, S. R. 2004. A perspective on the measurement of time in plant disease epidemiology. Plant Pathol. 53:705-712.

15. McCartney, H. A., Foster, S. J., Fraaije, B. A., and Ward, E. 2003. Molecular diagnostics for plant pathogens. Pest Manage. Sci. 52:129-142.

16. Oxley, S. J. P., Cooke, L. R., Black, L., Hunter, A., and Mercer, P. C. 2003. Management of Rhynchosporium on different barley varieties and cropping systems. Home-Grown Cereals Authority (HGCA) Proj. Rep. No. 315

17. Reitan, L., Gronnerod, S., Ristad, T. P., Salamati, S., Skinnes, H., Waugh, R., and Bjornstad, A. 2002. Characterization of resistance genes against scald (Rhynchosporium secalis (Oudem.) J. J. Davis) in barley (Hordeum vulgare L.) lines from central Norway, by means of genetic markers and pathotype tests. Euphytica 123:31-39.

18. Sambrook, J., Fritsch, E. F., and Maniatis, T. 1989. Molecular Cloning: A Laboratory Manual, 2nd ed. Cold Spring Harbor Laboratory, Cold Spring Harbor, NY.

19. Tottman, D. R. 1987. The decimal code for the growth-stages of cereals, with illustrations. Ann. Appl. Biol. 110:441-454.

20. Ward, E., Foster, S. J., Fraaije, B. A., and McCartney, H. A. 2004. Plant pathogen diagnostics: Immunological and nucleic acid-based approaches. Ann. Appl. Biol. 145:1-16.

21. Wheeler, J. E., Kendall, S. J., Butters, J., Hollomon, D. W., and Hall, L. 1995. Using allele-specific oligonucleotide probes to characterize benzimidazole resistance in Rhynchosporium secalis. Pestic. Sci. 43:201209.

22. Zhang, J., and Stewart, J. M. 2000. Economical and rapid method for extracting cotton genomic DNA. J. Cotton Sci. 4:193-201.

23. Zurawski, G., and Clegg, M. T. 1984. The barley chloroplast DNA AtpBE, trnM2, and trnV1 loci. Nucleic Acids Res. 12:25492559. 